\title{
THE USE OF BUDGETS IN FORECASTING THE ACTIVITY OF THE FIRM
}

\author{
Ph.D.Mariana MAN \\ The University of Petroşani \\ Ph.D.Mitran DANIELA \\ "Athenaeum" University Bucharest
}

\author{
Ph.D.Ioan C. DIMA \\ "Valahia" University of Targoviste
}

\begin{abstract}
The firm's activity is recommended to develop in a permanent equilibrium between incomes and expenses. In the actual stage of transition of Romanian economy, the firms can not maintain this equilibrium because the expenses determined by the achievement of production overtake the level of the incomes obtained from the selling of production even when certain branches of activity are subsidized from the public budget.

In these conditions, finding the methods that allow the sizing and control of the equilibrium relation between expenses and incomes represents a problem with which the firm's management confronts. From this point of view the budget can become an instrument of correlation and especially of turning to good account the relation between incomes and expenses. Budgeting becomes a systematic economic practice that assumes the development of a process of formal assignment of financial resources that aim at the achievement of some established objectives for the future periods.
\end{abstract}

Key-words: budget, budgeting, forecasting, management by using budgets, expenditure budget, budget holders, manufacturing costs.

JEL classification: M41, M11, L71

\section{INTRODUCTION}

Nowadays budget is a plan expressed in money through which the shares of the afferent resources for achieving an aim by a certain managerial subdivision are estimated in a financial expression. Budgets are established on short run periods, on a year with a breakdown by quarters, months, weeks and even day as for each job. When the firm's activities are varied, budgeting adapts to this situation through establishing some flexible budgets, elaborated on several levels of activity. Budgeting resides in presenting in a scheduled form the data that make up the budget.

Budgeting makes necessary the establishment of budgets that allow the presentation in figures of all forecasts on the activity of the firm. In essence it arises the problem of creating some autonomic subsystems called cost centers that 
should focus on the optimization of the use of resources and obtaining profits. The cost center is an identifiable function or part of the organization for which costs can be identified. A profit center is an extension of this idea on a larger scale, where not only costs are identifiable but also profits. The formal definition is that of a part of a business accountable for costs and revenues.

A budget center is defined as a section of an entity for which control may be exercised and budgets prepared. Thus it will be apparent that a budget center may be a cost center, or group of cost centers or it may coincide with a profit center. Because of its size it is likely that a typical profit center would consist of a number of budget centers each of which would contain either a single cost center or a group of related cost centers.

\section{THE USE OF BUDGETS IN THE MANAGEMENT OF THE FIRM}

Budgeting, both at the level of the organizational sub-firms of the firm as well as at the firm's level implies the drawing up of a system of budgets corresponding to the firm's system of objectives. Implementing management through budgets supposes respecting some stages, namely:

$>$ sizing the objectives under the form of financial indicators, takes place beginning with the superior hierarchical level and continuing with the deduction, being detailed in a certain degree allowed by the informational system of the firm, and it ends with the level of the departments from the formal structure of the firm. The used data are based on the forecasts elaborated on the basis of the analysis of the last drawn up budgets and book-keeping from the field of the budget;

$>$ elaborating the budgetary system at the firm's level is made according to the formal structure (on hierarchical levels and departments) and on the main fields of activity (production, sales, investments etc.);

$>$ organizing the informational system in order for the budget to be filled in, ensures the necessary information in this purpose upwards (opposite to the direction of drawing up budgets and establishing the objectives), meaning from the levels that allow the expression in adequate units of measure;

$>$ the coordination of the system of budgets takes place in order to eliminate the eventual discrepancies between the sub-budgets of the Master Budget, therefore the starting point will be the sales budget, on the basis of which the other budgets (of production, cash etc.) will be sized until reaching the Master Budget;

$>$ the control and the evaluation of results are necessary in order to establish the deviations from the objectives level and adopting some measures corresponding to the forecasted objectives. The drawing up of some intermediary budgets (on sub-periods) is needed in order to ensure an efficient control. On the basis of this budget, the analysis in time of the integration of the real situation in the budgetary provisions is made. 
The implementation of management by using budgets is based on expressing the objectives in financial terms, which allow management to have a permanent control on financial resources but not only on them. Thus, it is possible for managers to concentrate their efforts on the cutting of production costs and on the increase of the efficiency of the firm's activity. But, putting into practice this management system also has a series of limits such as: the large volume of labor necessary in order to fill in the applications needed in this method, decreased efficacy as result of some long informational circuits etc.

The data comprised in the budgets can be used in the drawing up of the manager's command panel that is a labor technique, of the manager of a firm or of a part of a firm, allowing him to know the evolution of his activity results. This one can not usually contain all the aspects of his managerial activity especially when the domain he leads is vast.

In this situation he will find himself in position to select, by using this command panel, the eloquent indicators for the evolution of his field of responsibility.

So, the command panel regroups and presents, under a selective form, the eloquent indicators also known as key points or signals, which allow the responsible of the ensemble or part of a firm to control its own field of responsibility.

In the specialized literature there are also used notions such as; general, commercial financial etc. command panel.

Even if there are various concepts regarding the, still it is always regarded as a instrument of labor, control, forecast and plan of the actions connected to a responsibility field of the firm.

Certain command panels are the result of a purely budgetary concept, which regroups a form of budgetary control and comprises the deviance characteristic to the management of budgets.

Other command panels comprise information coming from other sources than the ones of the budgetary and accounting systems namely: information from the commercial field (the segment of the market covered by the firm, the sizes of global market, the evolution of raw materials prices etc.); information from the financial field (quotations, rates of interest etc.).

Obviously in the introduction and establishment of command panels there are certain differences, meaning that certain command panels are elaborated with a weekly or twice a month periodicity, other with a monthly periodicity etc.

Also, there are command panels that can be established in a hierarchic concept comprising information corresponding to each field of activity.

For example, in a firm, a command panel comprises on one hand a commercial command panel (made up in its turn of panels on products or on areas and distribution networks, all these being regrouped at the level of this commercial 
command panel) and command panels made up on sections or on workshops regrouped in an industrial command panel on the other hand and, finally, a general command panel that regroups the financial command panel, the commercial command panel and the industrial command panel.

Finally, the presentation of command panels can be done in several ways. It is advisable that the form of presentation to avoid overloading and most of the time they should be accompanied by graphs, through which a clear representation of the firm's activity is done (diagrams with columns, diagrams that present the monthly or thew cumulated evolutions of certain indicators).

The content of the command panel, conceived on the basis of the data from the budget, should present those elements of the command panel, which are in a direct relation with the process of budgetary control in order to emphasize in this way the utility of the budget in the management of the firm.

From this point of view, the command panel in conceived under the form of a model with the highest degree of generalization, without the presence of any indicator that could be considered specific to a certain function or a certain field.

Conceived in a way that is the consequence of a budgetary method based on the usage of standards, this type of command panel can not be applied for all firms(especially for those which do not adopt the standards method).

Such a command panel comprises four parts that permit the control of the firm's activity and of the budget's, ensuring at the same time the establishment of some links with the general exploitation account, with the rolling of goods (inputs and outputs from stocks), with the variation of the elements from the balance and with treasury.

These are:

$>$ Elements of the commercial activity, comprised in the first part of the command panel that regroups the purely commercial information which refer to:

a) the analysis of the orders received and met comparatively with their forecasted level, namely the ones that emphasize in the Orders Card, drawn up in value and quantitative expression, if the soled products are homogenous or equivalent. The Orders Card is filled in with the corresponding turnovers (chart no.1 and chart no. 2). The orders from the chart will be presented with the help of graphs, for example: the graph of the dynamics of orders, received and met; the graph of the achievements comparatively to the level of the forecasted objectives etc. (fig.no.1); 
Chart no.1

Firm....

Month...

\section{Orders card (value)}

Sheet...

\begin{tabular}{|l|l|l|l|l|l|l|}
\hline \multirow{2}{*}{$\begin{array}{l}\text { Perioct } \\
\text { Specification }\end{array}$} & \multicolumn{3}{|c|}{ Monthly } & \multicolumn{3}{c|}{ Cumulated } \\
\cline { 2 - 7 } & Achieved & Budgeted & Deviations & Achieved & Budgeted & Deviations \\
\hline Opening balance & & & & & & \\
\hline + Registered orders & & & & & & \\
\hline - Invoicements & & & & & & \\
\hline = Closing balance & & & & & \\
\hline $\begin{array}{l}\text { Closing prevision of card's } \\
\text { balance (the previous year) }\end{array}$ & & & & & \\
\hline Revision of annual/ monthly objective & & & & \\
\hline Percentage of the achievement of the annual/ monthly objective & & & \\
\hline
\end{tabular}

Chart no.2

Firm....

Month...

\section{Orders card (quantitative)}

Sheet...

\begin{tabular}{|l|l|l|l|l|l|l|}
\hline \multirow{2}{*}{$\begin{array}{l}\text { Perioct } \\
\text { Specification }\end{array}$} & \multicolumn{3}{|c|}{ Monthly } & \multicolumn{3}{c|}{ Cumulated } \\
\cline { 2 - 7 } & Achieved & Budgeted & Deviations & Achieved & Budgeted & Deviations \\
\hline Opening balance & & & & & & \\
\hline + Registered orders & & & & & & \\
\hline - Invoicements & & & & & & \\
\hline = Closing balance & & & & & & \\
\hline $\begin{array}{l}\text { Closing prevision of card's } \\
\text { balance(the previous year) }\end{array}$ & & & & & \\
\hline Revision of annual/ monthly objective & & & & & \\
\hline Percentage of the achievement of the annual/ monthly objective & & & \\
\hline
\end{tabular}

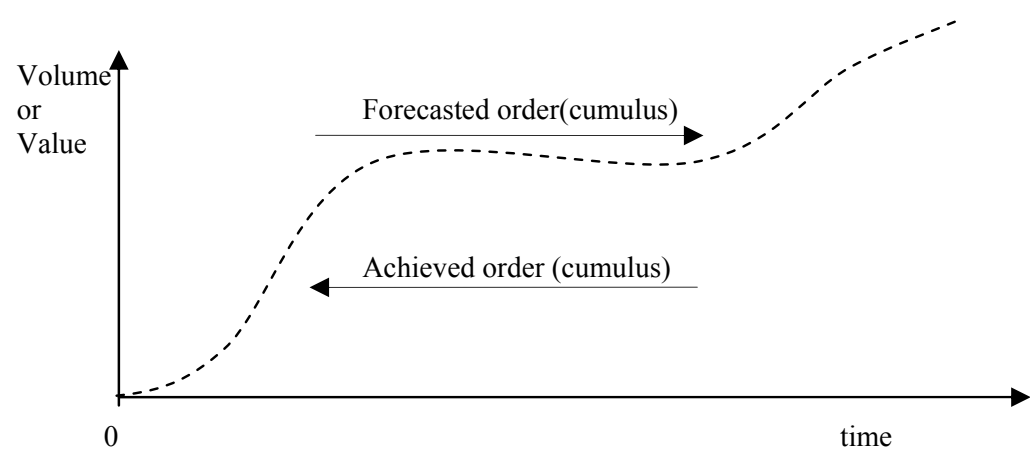

Figure no. 1 Correlation between the forecasted order and the achieved order 
b) the dynamics of the market shares owned by the firm or which are going to be owned.

This can be rendered under two forms:

1) chart representation (chart no. 3):

Chart no.3

Dynamics of market shares

\begin{tabular}{|c|c|c|c|c|c|c|c|c|}
\hline \multirow{2}{*}{$\begin{array}{l}\text { Specification } \\
\text { Periods }\end{array}$} & \multicolumn{2}{|c|}{$\begin{array}{l}\text { Total market; } \\
\text { No. of units }\end{array}$} & \multicolumn{2}{|c|}{$\begin{array}{l}\text { Market share } \\
\text { forecasted in \% }\end{array}$} & \multicolumn{2}{|c|}{$\begin{array}{c}\text { Market share } \\
\text { forecasted in no. of } \\
\text { units }\end{array}$} & \multicolumn{2}{|c|}{$\begin{array}{l}\text { Deviation } \\
\text { expressed in: }\end{array}$} \\
\hline & Budgeted & Achieved & Budgeted & Achieved & Budgeted & Achieved & Percentage & Units \\
\hline $\begin{array}{l}\text { Month no. } 1 \\
\ldots \\
\text { Month no.. n }\end{array}$ & & & & & & & & \\
\hline Total & & & & & & & & \\
\hline
\end{tabular}

This chart can also be represented under the form of a graph with columns or under the form of a diagram through the help of surfaces;

2) the graphic representation of the dynamics of the products supplied on the market, under the form of multi-dimensional diagram. This allows visualizing the new products and the products of the firm. Such a diagram represents the evolution of the new products market with the help of four parameters: the price of the consumed raw materials, the capacity or the size of the firm (fig. no. 2);

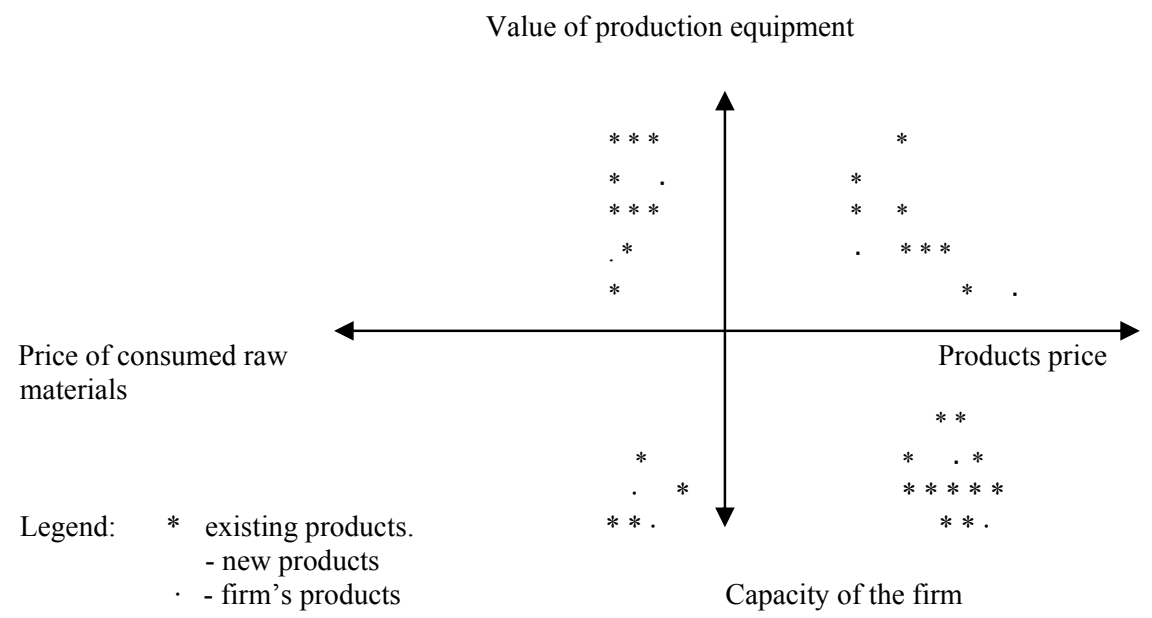

Figure no. 2 Graphic representation of the evolution of new products market

c) the structure of commercial assets regroups in the command panel the main assets which are in the responsibility of the sales department (the stocks of finished products and the customers' debts to the firm) under the form of a chart (chart no. 4). 
Structure of commercial assets

Chart no.4

\begin{tabular}{|c|c|c|c|c|}
\hline $\begin{array}{l}\text { Specification } \\
\text { Commercial assets }\end{array}$ & $\begin{array}{l}\text { Beginning of the } \\
\text { previous month }\end{array}$ & Inputs & Outputs & $\begin{array}{l}\text { End of the } \\
\text { previous month }\end{array}$ \\
\hline \multicolumn{5}{|l|}{$\begin{array}{l}\text { a) Stocks } \\
\text { - Stock of finished products (in conversion } \\
\text { costs) }\end{array}$} \\
\hline - $\quad$ Stock of finished products (in complete costs) & & & & \\
\hline \multicolumn{5}{|l|}{ - $\quad$ Value of stocks in selling prices } \\
\hline \multicolumn{5}{|l|}{ Up to what date the payment of the sold products in made } \\
\hline \multicolumn{5}{|l|}{ No. of days } \\
\hline \multirow[t]{2}{*}{ b) Customers } & \multirow{2}{*}{\multicolumn{2}{|c|}{$\begin{array}{l}\text { Beginning of the previous } \\
\text { month }\end{array}$}} & \multicolumn{2}{|c|}{ End of the previous month } \\
\hline & & & $\begin{array}{l}\text { According } \\
\text { to forecasts }\end{array}$ & $\begin{array}{l}\text { Deviations from } \\
\text { the forecasts }\end{array}$ \\
\hline - $\quad$ Customers to export & & & & \\
\hline Customers forecasted in the Orders Card & & & & \\
\hline - $\quad$ En-gross customers & & & & \\
\hline \multicolumn{5}{|l|}{$\begin{array}{l}\text { - Bills receivable that have not fallen due } \\
\text { (undue) }\end{array}$} \\
\hline - $\quad$ Bills now being discounted (undue) & & & & \\
\hline - $\quad$ Bills in portfolio & & & & \\
\hline \multicolumn{3}{|c|}{ No. of days of previous sales for which the payment has not been made } & \multicolumn{2}{|c|}{ Calculations for cumulus } \\
\hline
\end{tabular}

The presentation of the elements of commercial assets is completes in a suggestive way by the diagram of the dynamics of the finished products stocks, the diagram of the customers' accounts and the diagram of the terms of the accounts given to customers.

$>$ Elements destined to the synthesis of the exploitation budget represent that part that comprises the exploitation account extracted from the budgetary control (chart no. 5).

The elements of the command panel that are related to the exploitation activity will be, just like the commercial elements, completed suggestively with graphs that permit the visualization of certain elements emphasized through these command panels, for example: deviations, gross margins etc.

Revision chart of the exploitation control

Chart no.5

\begin{tabular}{|l|l|l|l|}
\hline $\begin{array}{l}\text { Specification } \\
\text { Indicators }\end{array}$ & Budgeted & Achievements & Deviations \\
\hline $\begin{array}{l}\text { Net commercial share + Industrial result - } \\
\text { Structure expenses of the firm }\end{array}$ & & & \\
\hline = Economic result of the firm & & & \\
\hline - Liquidates & & & \\
- Tenancies & & & \\
- Leasing & & & \\
- Financial structure expenses of the firm & & & \\
\hline - Managerial result & & & \\
\hline $\begin{array}{l}\text { - Subtractions from the revaluation of stocks and } \\
\text { from the standards' variation }\end{array}$ & & & \\
\hline$=$ Accounting result & & & \\
\hline
\end{tabular}


The elements that highlight the firm's means are comprised in the third part of the command panel which is designed for the control of the firm's means in order to achieve its objectives that regard the following: force of men employed and its variation; investments; the means of production that comprise stokes, products now being manufactured, suppliers (chart no. 7). This chart, representing the third part of the command panel, is also completed by graphs such as: the graph of the personnel's dynamics; the graph of the dynamics of the stocks of raw materials and products now being manufactured etc.

Elements reflecting the evolution of treasury are comprised in the part of the command panel that results directly from the budgetary control process that comprised: the control of the cash budget; a quarter forecast (for the three following months) of the treasury; the situation of the treasury. Just like the other parts of the command panel, the part reflecting the evolution of the treasury can be illustrated through graphs, which prove their utility in the managerial activity. So, the command panel can be presented in a centralized form, which comprises a chart with two lines ad two columns, corresponding to its four parts that are interconditioned (chart no. 6).

\section{Manager's command panel}

Chart no.6

\begin{tabular}{|l|l|}
\hline $\begin{array}{l}\text { Part I } \\
\text { Elements of the commercial activity }\end{array}$ & $\begin{array}{l}\text { Part II } \\
\text { Elements destined for the synthesis of the } \\
\text { exploitation budget. }\end{array}$ \\
\hline $\begin{array}{l}\text { Part III } \\
\text { Elements that highlight the means of the firm. }\end{array}$ & $\begin{array}{l}\text { Part IV } \\
\text { Elements reflecting the evolution of treasury. }\end{array}$ \\
\hline
\end{tabular}

Chart no.7

Emphasizing the firm's means

I No. of employees

\begin{tabular}{|l|l|l|l|l|l|}
\hline $\begin{array}{l}\text { Employees' } \\
\text { structure } \\
\text { Specification }\end{array}$ & Workers & $\begin{array}{c}\text { TESA } \\
\text { employees }\end{array}$ & Leading staff & $\begin{array}{c}\text { Other } \\
\text { employees }\end{array}$ & Total \\
\hline Beginning of month & & & & & \\
\hline Inputs & & & & & \\
\hline Outputs & & & & & \\
\hline End of month & & & & \\
\hline
\end{tabular}

II Investments

\begin{tabular}{|l|l|l|}
\hline $\begin{array}{l}\text { Speeification } \\
\text { Structure } \\
\text { of investments }\end{array}$ & Month & Cumulus at the datum... \\
\hline External purchases & & \\
\hline $\begin{array}{l}\text { Production of premises } \\
\ldots\end{array}$ & & \\
\hline Total & & \\
\hline
\end{tabular}


III. Means of production

A. Stocks

\begin{tabular}{|l|l|l|l|l|}
\hline $\begin{array}{l}\text { Specification } \\
\text { The nature } \\
\text { of stocks }\end{array}$ & $\begin{array}{c}\text { Beginning of } \\
\text { month }\end{array}$ & Inputs & Outputs & $\begin{array}{c}\text { End of } \\
\text { month }\end{array}$ \\
\hline $\begin{array}{l}\text { Raw materials } \\
\text { - Products now being } \\
\text { manufactured } \\
\ldots\end{array}$ & & & & \\
\hline Total & & & \\
\hline Number of days of stocks' consumption & & & \\
\hline
\end{tabular}

B. Suppliers

\begin{tabular}{|l|l|l|}
\hline $\begin{array}{l}\text { Specification } \\
\text { Nature of debts }\end{array}$ & Beginning of month & End of month \\
\hline $\begin{array}{l}\text { - Suppliers for the exploitation activity } \\
\text { - bills to be paid to suppliers } \\
\text { • Receivable exploitation invoices } \\
\ldots\end{array}$ & & \\
\hline Total & & \\
\hline No. of days for supply & & \\
\hline
\end{tabular}

\section{THE USE OF BUDGETS IN FORECASTING CONVERSION COSTS}

The present chapter focuses on the characteristics of the firms from the mining carboniferous industry. It can be considered that one of the reasons for which mine carboniferous workings have registered losses in the last years, is the fact that returns and expenditures budget focuses only on the global level of each mine working. In this budget the expenses are established on the whole and they are divided on types of expenses according to their nature. Thus, the manager of the mine working and the economic manager are responsible for the appropriate observance of the level of the expenses forecasted in the budget. That is why it is better for the expenditures budgets to be drawn up more analytically, namely on different hierarchical levels of the mine working and each budget should be also linked to a budget holder.

In this way, the expenditures budget in drawn up for one year. The annual budget is divided in quarters and monthly budgets that are allocated on specific structural-organizational divisions called "expenditures centers (places)". An expenditure center will have in charge a partial budget, which is a component of the annual master budget. The distribution of the responsibilities on expenditure centers can be done in a hierarchical way just as it is presented in figure no. 3 .

The main stages of drawing up expenditure budgets are the following: the establishment of responsibilities on different levels of organization; the establishment, on each center, of the costs that must be controlled by the responsible of the center, as a decisional factor on that hierarchical level; the forecasting of the coordinates of that center taking into account the forecasted level of the center's activity and the prices and tariffs negotiated by the supplying and 
beneficiary units; the sizing of costs really registered; the comparison of the achievements with the forecasts for that period, the identification of the deviation and the evaluation of the tendency of the respective center; the drawing up of expenditures budget at the center level; the negotiation at the superior level of decision, regarding the dimension of the required budget; the agreement upon the revised budget and the assumption of responsibility of the expenditure centers for the administration and achievement of the desired profit.

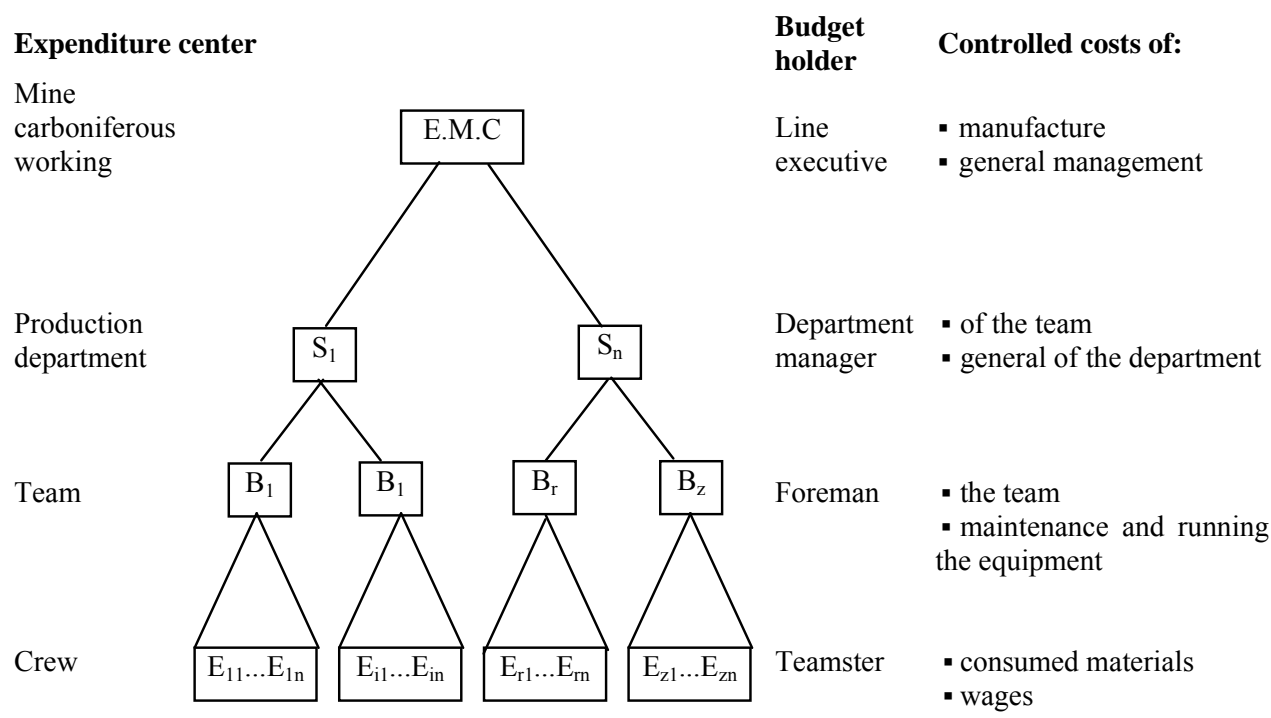

Figure no. 3. Description of expenditure centers, budget holders and costs that are to be controlled at the level of mine working

The drawing up of expenditure budget starts with communicating the details related to the forecasting policy of coal mining and the actions, which must be taken by the ones responsible for the preparation of partial budgets. The main data sources used for drawing up the annual expenditure budget are the forecasts of the management regarding the possible levels of the different actions and the bookkeeping that contain the indicators specific to past and present operations.

The sizing of budgets focuses not only on the hierarchical relations between the subsystems of mine working but also on the functional relations, which imply the dependency of one budget upon another, according to the relation inputsoutputs (fig. no. 4)

The holders of the expenditure centers prepare the basic data of sizing the budget and they are responsible for its achievement. Thus, budgetary technique implies the development of the attributes of forecasting, organization, coordination and control of the management through expenditures. Moreover, the management 
through expenditure budgets is of great help to communication and to drawing up the tactical and strategically decisions in order to regulate the coal mining activity.

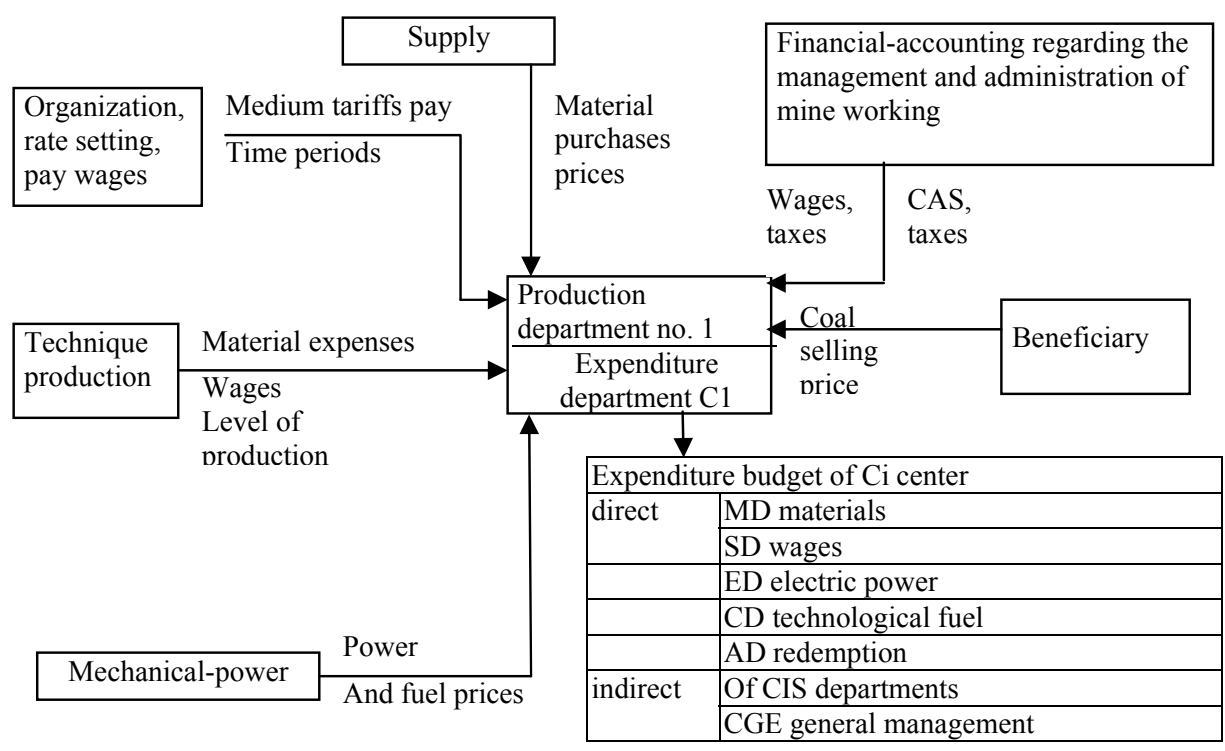

Figure no. 4. Drawing up expenditure budget, at the level of a production center on the basis of the informational system and the functional relationships between departments

The model of the expenditure budget $(B C)$ of coal mining can be based on a relation made up of several terms, respectively more partial expenditures budget, as it follows:

$$
\mathrm{BC}=\mathrm{MD}+\mathrm{SD}+\mathrm{ED}+\mathrm{CD}+\mathrm{AD}+\mathrm{CIS}+\mathrm{CGE}
$$

where: $M D$ - represents raw materials and direct materials expenditures budget;

$S D$ - direct wages expenditure budget (including the contributions to these);

$E D$ - budget of power direct expenses for technological purposes;

$C D$ - direct expenses budget of technological fuel;

$A D$ - direct expenditures budget of fixed means redemption;

$C I S$ - indirect expenditures budget of departments;

$C G E$ - general management expenditure budget

It must be mentioned that coal-mining activities do not lead to sale costs and this is the reason why in the above relation the sale costs budget was not present. This happens because coal sale is ensured by the preparation operations of the coal that takes place as distinct units.

In what follows the expenditure center is considered as a production sector within a mine working. The production sector represents a structural subdivision well defined from the point of view of its management. All the stages of coal mining take place in this subdivision and they start with the preparation of the 
working grounds and end with bringing to surface the extracted quantity of coal. The representation from figure no. 4 will be used in order to understand the structure of an expenditures budget of the specific center marked with $\mathrm{C} 1$.

\section{THE GENERAL BUDGET OF MANUFACTURING COSTS}

The general budget of manufacturing costs of mine carboniferous working can be drawn up by summing up the seven types of partial budgets presented in above: the raw materials and direct materials expenditure budget, direct wages expenditure budget and their afferent taxes; electric power direct expenditure budget; technological fuel direct expenditure budget; budget of direct expenses with redemption; manufacturing (common) indirect costs budget of the departments and the general administrative expenditure budget.

The model of the general administration expenditure budget drawn up for a mine carboniferous working is presented in chart no. 8 .

General administration expenditure budget

Chart no.8

\begin{tabular}{|l|l|l|}
\hline Name of component budgets & $\begin{array}{l}\text { Preliminary year } \\
\mathrm{N}-1\end{array}$ & $\begin{array}{l}\text { Forecasted year } \\
\mathrm{N}\end{array}$ \\
\hline Raw materials and direct materials budget & 6856541,83 & 8902449,36 \\
Direct wages expenditures budget and their afferent taxes & 45450902,95 & 51417489,88 \\
Electric power direct expenditures budget & 7395701,48 & 9438105,60 \\
Technological fuel direct expenditures budget & 209317,54 & $304.614,57$ \\
Budget of direct expenses with the fixed means & 982004,00 & 995111,00 \\
redemption & & 3200000,00 \\
Indirect (common) manufacturing costs budget of the \\
department & 3200000,00 & 3781200,00 \\
General administration expenditures budget & 3599350,00 & $\mathbf{7 8 0 3 8 9 7 0 , 4 1}$ \\
\hline Total & $\mathbf{6 7 6 9 3 8 1 7 , 8 0}$ &
\end{tabular}

\section{CONCLUSION}

Budgeting is characterized by:

$>$ planning and coordination because budgeting works within the framework of a long term, overall objectives to produce detailed operational plans for different sectors and facets of the organization. This is expressed in the form of a Master Budget, which summarizes all the supporting budgets. The budget process forces managers to think of the relationship of their function or departments with others and how they contribute to the achievement of organizational objectives;

$>$ authority and responsibility, because budgeting makes it necessary to clarify the responsibilities of each manager who has a budget. The adoption of a budget authorizes the plans contained within it so that the management by exception can be practiced, meaning that a subordinate is given a clearly defined role with the authority to carry out the tasks assigned to him and when activities are not proceeding to plan, the variations are reopened to a higher level; 
$>$ communication, because the budgetary process includes all levels of management. Accordingly it is an important avenue of communication between top and middle management regarding the firm's objectives and the practical problems of implementing these objectives and, when the budget is finalized, it communicates the agreed plans to all the stuff involved;

$>$ control, because this aspect of budgeting is the most well- known and is the aspect most frequently encountered by the ordinary stuff member. The process of comparing actual results with planned results and reporting on the variations, which is the principle of budgetary control sets a control framework which helps expenditure to be kept within agreed limits;

$>$ motivation, because the involvement of lower and middle management with the preparation of budgets and the establishment of clear targets against which performers can be judged have been found to be motivating factors.

Taking into account the characteristics of budgeting it can be said that the budget, as a working instrument, has the following features: it ensures the integration of forecasting activities, of the evidence and control of costs, incomes and financial results; it allows the decentralization of the management process through the division of firm's activities on responsibility centers; invests each center with authority an responsibility in the management of resources in order to achieve the aimed objectives; approaches the activity of each center through the costs- incomes relation and, on this basis, it ensures its participation in the increase of the firm's profitability and in the saving of its resources.

As a working instrument of the manager, the budget has a series of functions namely:

$>$ the forecasting function is based on the fact that the budget represents the financial estimation of the level of resources, funds and expenses for all the socioeconomic activities that develop in the firm. Through budget, the incomes, expenses and financial results regarding the basic production activity, the resources and capital expenditures, resources and expenses for the circulating assets, the other resources and expenses due to production, including taxes, rates and other debts to the public budget;

the control function manifests when the expenses are established and done, the incomes are achieved as results of the own activity and the necessary funds are created. In this quality the budget gives an organizing expression to the control function of finances. It comes to terms with the financial prevention control regarding the firm's funds establishment and spending. The control function of the budget is exercised trough analyzing and following the manner in which it is executed, through which there are ensured the following: the knowledge on the way in which the planned duties are accomplished; determining the deviations; 
establishing the causes that have generated the deviations; the compartments that have to act for the improvement of the activity etc.;

$>$ the function of ensuring financial equilibrium is based on the fact that the budget is used in order to direct and control the balanced relations between costs and incomes. At the firm's level the financial equilibrium reflects the ensuring of the financial resources necessary for the achievement of the planned objectives and actions including the fulfillment of payment obligations towards third parties.

\section{Bibliography}

1. Calin, O., Man, M., Nedelcu, M. - Contabilitate manageriala, Editura Didactica si Pedagogica RA, Bucuresti, 2008;

2. Dima, I.C., Man, M. - Managementul activității industriale, Editura Academiei Romane, Bucuresti, 1999;

3. Man, M., Cucui, I. - Costurile şi controlul de gestiune, Editura Economica, Bucuresti, 2004;

4. Man, M., Vilkul, I. - Previzionarea costurilor producției firmei în economia de piață, Editura Universitas, Petroşani, 2006. 